\title{
MODERN DÖNEM Şiî DÜŞÜNCESINDE BiR KIMLIK INSSASI OLARAK ERBAîN YÜRÜYÜşÜ
}

\section{Habip DEMiR}

Hitit Üniversitesi, Illahiyat Fakültesi, İslam Mezhepleri Tarihi ABD, Çorum/Türkiye habibdemir06@gmail.com, https://orcid.org/0000-0003-4360-3410

\author{
Article Types / Makale Türü \\ Research Article / Araştırma Makalesi
}

Received / Makale Geliş Tarihi

07/02/2021

\section{Accepted / Kabul Tarihi}

22/03/2021

Doi: https://doi.org/10.26791/sarkiat.876043 


\section{MODERN DÖNEM Şiî DÜŞÜNCESINDE BiR KIMLIK INŞASI OLARAK ERBAîN YÜRÜYÜŞÜ}

\section{ÖZ}

Dinler ve mezhepler, aidiyet duygularının korunması ve gelecek nesillere aktarılması için geçmişin her an yeniden yaratılmasını sağlarlar. Bunun en önemli araçlarından birisi de dinî ritüellerdir. Şiîlik, ritüele dayalı dindarlığın en yaygin olarak görüldügü ekollerden birisidir. Şiîliğin siyasî bir hareketten teolojik bir evreye geçişinde ve mezhebî aidiyetlerin kazandırılmasında Kerbelâ hadisesi oldukça önemli bir rol oynamıştır. Şiî gelenekte, Hz. Hüseyin'in ölümünün kırkınc1 günü olarak özel bir anlama kavuşan Erbaîn ziyareti ve yürüyüşü, Şiîliğin toplumsal alana nüfuz edip sistemleşmesinde önemli bir işlev üstlenmiştir. Başlangıçta daha çok Iraklı Şiîler tarafından yerel bir görünüm arz eden Erbaîn yürüyüşü, son dönemlerde uluslararası boyuta ulaşan bir etkinliğe dönüşmüştür. Dünyanın çeşitli bölgelerinden gelen ziyaretçiler, Necef ile Kerbelâ şehirleri arasındaki yaklaşık seksen kilometrelik yolu birkaç günde yürüyerek kat etmekte, bu yürüyüşs sırasında gerçekleştirilen çeşitli etkinliklerle sosyal kimliğin gelişmesine katkıda bulunmaktadırlar. $\mathrm{Bu}$ etkinlik, sosyal ve dinî yönünün yanında İran'ın hem diğer Şiîlere hem de başta Suudi Arabistan olmak üzere bölge ülkelerine karşı kullanabileceği siyasî bir boyut da kazanmıştır. Bu yürüyüşün önümüzdeki dönemlerde daha da vurgulanarak Şiî kimliğin ikamesinde alternatif bir araç haline geleceği görünmektedir. Çalışmamız, Erbaîn yürüyüşünü, kimlik ve aidiyet bağlamında disiplinler arası boyutta inceleyerek alana katkı sunmayı hedeflemektedir.

Anahtar Kelimeler: İslam Mezhepleri Tarihi, Kerbelâ, Ziyaret, Erbain, İran, Irak

\section{THE ARBA'EEN MARCH AS A IDENTITY CREATION IN MODERN SHI'ITE THOUGHT}

\section{ABSTRACT}

Religions and sects ensure that the past is always recreated in order to protect their sense of belonging and pass it on to future generations. One of the most important tools of this is carried out through religious rituals. Shiism is one of the schools of thought in which ritualistic religiosity is most common. The case of Karbala played an important role in the transition of Shiism from a political movement to a theological phase and in gaining sectarian belongings. In the Shiite tradition, the visit and march of Arba'een, which gained a special meaning as the 40th day of Husain's death, played an important role in the penetration and systemization of Shiism in the social sphere. The Arba'een march, which initially had a local appearance mostly by Iraqis, has recently turned into an event that has reached an international dimension. Visitors from various parts of the world travel the approximately eighty-kilometer road between Najaf and Karbala cities in a few days and contribute to the formation of social identity with various activities during this walk. In addition to its social and religious aspects, this activity has also gained a political dimension that Iran can use against other Shiites and the countries of the region, especially Saudi Arabia. It seems that this march will be emphasized more in the coming periods and will become an alternative tool in the substitution of Shiite identity. Our study aims to contribute to the field by examining the Arba' $\mathrm{e}$ en march in an interdisciplinary dimension in the context of identity and belonging.

Keywords: History of Islamic Sects, Karbala, Ziyarat, Arba'een, Iran, Irak 


\section{GíRiş}

\imlik kavramının geçmişi oldukça eskilere gitmesine rağmen, modernleşme ve bunun neticesinde

Lelişen ulus devlet yapıları sürecinde bu kavram ve ona ait alt unsurlar, sosyal bilimlerin psikoloji, sosyoloji ve felsefe disiplinlerinde yaygın bir kullanım alanına kavuşmuştur.

Sosyal kimlik kuramına göre, bireyin sosyal kimliği, ait olduğu toplumsal gruplara göre belirlenmektedir. Bu kuram, bireyin üyesi olduğu sosyal gruplar, onun duygu, düşünce ve davranışlarını belirleyerek sosyal kimliğin sosyalleşme sonucunda elde edildiğini ileri sürmektedir. Dolayısıyla, birey olarak taşıd1ğımız kimliklerin belirginleşmesindeki en önemli etkenlerden birinin, kültür tarafından şekillenen farklı aidiyetlerimiz olduğunu söylemek mümkündür. ${ }^{1}$

Burada kimlik ile birlikte anılan "aidiyet” kavramına özel olarak değinmek gerekmektedir. Bireysel bir olgu olan kimliğin inşa edilmesinde insanın içinde yaşadığı toplumun millî, dinî, siyasal, ekonomik değer yargıları etkili olmakta ve bu değer yargıları onları bir kimlik aidiyetine yönlendirmektedir. Aşkın’ın “giydirilmiş kimlikler" olarak tanımladığı bu aidiyetler ile, toplumsal üretim araçları tarafından belli kimliklere sahip insanların üretilmesi kastedilmektedir. ${ }^{2}$ Öyleyse insanlar, doğuştan getirdikleri birtakım aidiyetlere sahip olmakla birlikte asıl kimlik bileşenlerini yaşam boyunca elde eder ve bu bileşenler sürekli bir değişim gösterebilir. ${ }^{3}$

Bireylerin sahip oldukları en önemli aidiyet unsurlarından biri de belirli gruplar yoluyla elde edilenlerdir. Birey olarak bir gruba ait olmanın en önemli koşullarından biri ise, o grubun ortak geçmişiyle yaşanan birliktelik ve bunun günlük pratiklere yansıması sonucu ortaya çıkar. Buna Assmann'ın deyimiyle kişinin "ortak bellek" ya da "kültürel bellek" sahibi olması denir. Bu bellek, düşüncenin taşıyıcıları yoluyla aktarrlarak nesilden nesile ulaşır. ${ }^{4}$

Assmann'a göre geleceğe taşınan düşüncelerin belli bir mekân ve zaman ile irtibatının kurulması, "hatırlama figürleri” olarak adlandırdığı ortak bellek araçlarıyla gerçekleşmektedir. Böylece bu düşünceler, belli bir mekâna özgü kılınmakta ve belli bir zaman diliminde sürekli olarak güncelleştirilmek istenmektedir. Bunun sonucunda ortak bellek, bireylere somut bir dayanak noktası verir. Söz konusu mekanlara "maddi çevre" diyebileceğimiz onun dünyasını oluşturan, benliğinin taşıyıcısı ve destekleyicisi olarak ona ait olan şeyler de dahildir. Kendini diğerlerinden ayırt ederek grup kimliğiyle toplumsal muhayyilede sağlamlaştırmak isteyen her topluluk, kimliklerinin sembolü ve dayanak noktası olarak bu tür mekânları yaratmak ve bunları geleceğe taşımak ister. Bu nedenle kültürel bellek, mekân ile sıkı bir ilişki içinde olmak zorundadır. Grup ve mekân bir arada, sembolik bir ortak yaşam kurarlar; grup kendi mekânından ayrı düşse de bu birlikteliği, kutsal mekânları sembolik olarak yeniden üreterek yaşatır. ${ }^{5}$ Böylece mekân aracılığıyla toplum olma bilinci sürekli olarak korunmuş olmaktadır.

Kültürel belleğin en somut tezahürlerinden biri de insanoğlunun dinî tecrübesinde ortaya çıkmaktadır. Dinlerin en genel işlevlerinden biri, mensuplarının muhayyilesine hitap edecek toplumsal olguları hatırlama, canlandırma ve tekrarlama yoluyla geçmişin devamına aracı olmaktır. Dinler, geçmişin yaratılması eylemini belirli zaman aralıklarıyla tekrar eden bayramlar ve dini ritüeller aracılığıla yerine getirmektedir. Geçmişin şimdiki zaman diliminde sürekli olarak yaratılması, kültürel belleğin, yani bellek olarak kültürün evrensel işlevlerinden biridir. ${ }^{6}$ Böylece sürekli olarak tekrarlama ile geçmiş, her çağda yeniden üretilmekte ve güncellenmektedir. Bu güncellemenin en bariz şekilde toplumsal alanda görünür kılındığı faaliyetler ise

1 - Muhittin Aşkın, "Kimlik ve Giydirilmiş Kimlikler”, Atatürk Üniversitesi Sosyal Bilimler Enstitüsü Dergisi 10/2 (2010), 214-215.

2 - Aşkın, “Kimlik ve Giydirilmiş Kimlikler”, 216.

3 - Amin Maalouf, Ölümcül Kimlikler, çev. Aysel Bora (İstanbul: Yapı Kredi Yayınları, 2014), 25.

4 - Jann Assmann, Kültürel Bellek: Eski Yüksek Kültürlerde Yazı, Hatırlama ve Politik Kimlik, çev. Ayşe Tekin (İstanbul: Ayrıntı Yayınları, 2018), 28-33.

5 - Assmann, Kültürel Bellek, 46-47.

6 - Assmann, Kültürel Bellek, 92-93. 
ritüeller olarak karşımıza çıkmaktadır. Öyle ki ritüeli olmayan bir dinî tecrübeden bahsetmek neredeyse imkansızdir.

Ritüeller, zamanın belirli bir kısmında tekrarlanan olgular olmanın ötesinde çeşitli işlevlere sahiptir. Onun en önemli işlevlerinden biri, tekrarlama yoluyla kültürün yeni kuşaklara aktarılması sürecinde grup kimliği ve aidiyetlerini korumasıdır. ${ }^{7}$ İnancın ve buna dayalı olarak ritüellerin bireyler arasındaki gelenekle birlikte oluşmuş toplumsal bağları güçlendirdiği ve toplumsal değerleri kalıcı hale getirdiği sosyolojik bir gerçeklik olarak kabul edilmektedir. ${ }^{8}$ Y 1 boyunca tekrar eden ve belirli ritüellerle sürekli olarak kendini yenileyen kutsal zamanlar, zamanın yeniden dirilmesini, böylece yapılan ritüellerle geçmişte yaşanmış bazı anların ebedileştirilmesini sağlamaktadır. Evrenin simgesel bir şekilde yıllık olarak yeniden yaratılması düşüncesi, ilkel dinlerden bu yana dini gelenekleri etkileyen önemli bir olgu olmuştur. ${ }^{9}$

Tarihî süreçte kutsal simgeler ve ritüeller yoluyla toplumsal etkileşime dayalı mezhebî aidiyetlerin en önemli örneklerinden birini Şiî toplumun şekillenişinde görmek mümkündür. Şiîlik, azınlık olmanın getirdiği etkiyle diğer mezheplere nazaran toplumsal aidiyetlere göre biçimlenen ve bu aidiyetler ölçüsünde gücünü keskinleştiren bir mezhep olagelmiştir. Mezhepleri, tarihin belli bir döneminde ortaya çıkmış ve oluşumlarını tamamlamış yapılar olmanın ötesinde sürekli değişen ve tamamlanmamış süreçler olarak görmek gerektiği ön kabulünden hareketle ${ }^{10}$ Şiîliğin de toplumsal bilinç temelinde kendini sürekli güncelleyen bir mezhep olduğunun altını çizmek gerekir. Şiîlik, bu özelliğini yıl içerisinde gerçekleştirilen birçok hatırlama ritüeli ile canlı tutmaya özen göstermektedir. Bu konuda en fazla ritüele konu olan olay ise Hz. Hüseyin'in birçok aile mensubuyla birlikte Kerbelâ'da katledilmesi sürecinde yaşananlardır.

Şiî muhayyilede Kerbelâ, tarihin belirli bir döneminde gerçekleşmiş ve sona ermiş bir olay olarak görülmemektedir. Mezhebin kurumsallaşma sürecini tamamlamasının ardından Kerbelâ hadisesi, her dönemde yeni ve özgün içeriklerle geçmişin yeniden kurgulanması neticesinde tarihsel bir olay olma özelliğini kaybetmiş, "seçilmiş ve transfer edilmiş travma" haline getirilerek canlı tutulmuştur. Mezhepler, geçmişi yeniden inşa ederek mensuplarının aidiyet bilinçlerini güçlendirme amacı taşıdıkları için Kerbelâ'nın da bu amaçla tarih ötesi bir anlama büründürüldüğ̈ söylenebilir. ${ }^{11}$

İslam Mezhepleri Tarihi alanına dair çalışmaların disiplinler arası niteliği, sosyal bilimlerin diğer dallarıyla ilişkiye yönlendirmektedir. Bu nedenle çalışmamızda, sosyal bilimlerin en önemli kavramlarından biri olan "kimlik" ve "aidiyet" olgularının yaşayan bir mezhep olan Şiîliğin günümüzdeki en belirgin ritüellerinden biri olan Erbaîn ile irtibatının kurulması amaçlanmıştır. Bu konuda yapılan çalışmalar Şiîliğin daha çok Kerbela ve Âşûrâ merasimlerine odaklanmaktadır. Ancak özellikle son yıllarda gerek toplumsal kimlik ve aidiyet duygularını pekiştirme, gerekse uluslararası ilişkilerde stratejik önemi nedeniyle Erbaîn törenlerinin vurgusunun arttığı gözlemlenmiştir. Bu nedenle çalışmamızda, Erbaîn'in Şiî gelenekteki yeri ve önemine değindikten sonra modern bir olgu olarak Erbaîn yürüyüşleri özelinde Şiî düşüncenin geçirmekte olduğu yeni dönemin izleri takip edilmeye çalışılacaktır.

\section{Şiî GELENEKTE ERBAîN VE ÖNEMi}

Şiîlik'te toplumsal bilinci diri tutmak, bireyler arasındaki iletişimi kuvvetlendirmek ve mezhebin pratiklerini geniş bir toplumsal tabana yaymak, son derece önemli bir olgudur. Bu kapsamda Şiî toplumunun günlük,

7 - Assmann, Kültürel Bellek, 99.

8 - Clifford Geertz, Kültürlerin Yorumlanması, çev. Hakan Gür (Ankara: Dost Yayınevi, 2010), 169.

9 - Mircea Eliade, Dinler Tarihi: Inançlar ve İbadetlerin Morfolojisi, çev. Mustafa Ünal (Konya: Serhat Kitabevi, 2005$), 475$.

10 - Mehmet Kalaycı, "Mezhepleri veya Dinî Hareketleri Tamamlan(Ma)mış Kimliksel Süreçler Olarak Okumak”, Kur'an ve Toplumsal Bütünleşme (Mezhepler ve Dinî Gruplar Arası İlişkiler) (Bursa: y.y., 2015), 240.

11 - Kerbelâ olayının Şiî düşüncede geçirdiği dönüşümler hakkında bir analiz için bk. Hasan Onat, “Kerbela’yı Doğru Okumak” (Erişim 06 Mart 2021); Metin Bozan, “Tarihi Hadiselerin Konjonktürel İnşası (Şia'da Kerbela Örneği)”, Şarkiyat 9/2 (2017), 803 vd.; Söz konusu algı, tarihî süreçte yalnızca İmâmiyye mensuplarına özgüdür. Diğer Şiî firkalarda Kerbelâ’ya böyle bir anlamın verildiğine dair elimizde yeterli bilgi bulunmamaktadır. Konunun Zeydî firkalardaki yeri hakkında bir inceleme için bk. Mehmet Ümit, “Zeydiyye Mezhebi’nde Hz. Hasan, Hz. Hüseyin ve Kerbelâ”, Ilahiyat Akademi 5 (2017), 137 vd. 
haftalık, aylık ve yıllık olmak üzere çeşitli zaman dilimlerine has aktiviteleri bulunmaktadır. ${ }^{12}$ İmamların ve diğer mezhep büyüklerinin doğum ve ölüm yıldönümlerinde düzenlenen faaliyetler yanında "Kumeyl" ve "Tevessül" duaları gibi haftalık olarak toplumu birleştirici ve bir arada tutmaya yarayan etkinlikler en önde gelenler arasındadır. Ancak diğer ritüel ve uygulamaların yanında Şiî düşüncede Hz. Hüseyin'in şehadeti ve onun etrafında ortaya konulan birçok sembolik ve teolojik öğe, mezhebin adeta hayat kaynağı durumundadır.

$\mathrm{Bu}$ öğeler arasında en müstesna yeri olan ritüellerden birisi de Hz. Hüseyin'in şehadetinin kırkıncı günü olarak anılan Erbaîn ziyareti ve onunla birlikte geliştirilen etkinliklerdir. Şiî geleneğin en önemli günlerinden biri olarak görülen hicrî takvime göre 20 Safer günü, "Erbaîn-i Hüseynî” ya da “Erbaîn-i Seyyidü'ş-Şühedâ" olarak anılmaktadır. ${ }^{13}$ Yine bugün, Şiîler arasında Kerbelâ'da katledilen Hüseyin'in başının defnedildiği yere getirilmesinden mülhem olarak "Reddu'r-Re's” yani (Hüseyin'in) başının dönüş günü olarak da bilinmektedir. ${ }^{14} \mathrm{Bu}$ günde Hüseyin'in kabrinin ziyaret edilmesi ve çeşitli dualar okunması mezhebin en önemli ritüelleri arasına dahil edilmiştir.

Şiî gelenekte kırk sayısı ve faziletlerine dair çok sayıda rivayete rastlamak mümkündür. ${ }^{15}$ Kırk sayısına hem çeşitli kaynaklarda hem de toplumsal muhayyilede verilen önemin farkında olan Şiî düşünürlerden bazıları, rakamların bizatihi kendisine özel bir anlam yüklenmesine karşı olmakla birlikte söz konusu Erbaîn olduğunda ona ayrı bir yer açmak gerektiğini düşünmektedir. Hatta Erbâin'in önemini vurgulamak üzere “namaz nasıl dinin direği ise, Erbaîn ziyareti ve Kerbelâ da velâyetin direğidir.” şeklinde söylemlere de rastlamakmümkündür. ${ }^{16}$

Bu bağlamda Şiî gelenekte "Erbaîn” ya da "Erbaîn-i Hüseynî” olarak anılan Safer ayının 20. günü oldukça önemli bir simge haline gelmiştir. Hatta bu yönüyle kırkıncı günde özel olarak düzenlenen bir ziyaret şekli, Hüseyin dışında ne peygambere ne de imamların herhangi birisine atfedilmiştir. ${ }^{17}$ Dolayısıyla Erbaîn, bir ritüel olmanın ötesine geçerek başlı başına sembolik değere sahip bir olgu haline gelmiştir. ${ }^{18}$

Şiî gelenekte bugünün tarihî süreci tartışılırken ziyaretin bizatihi kendisi hakkında tartışma bulunmamaktadır. Henüz ilk dönemlerden itibaren Hz. Hüseyin'in kabrini ziyaret etmenin fazileti ve ayrıcalıkları üzerine geniş bir edebiyatın oluşmaya başladığı bilinmektedir. Onun kabrini ziyaret etmenin günahların bağışlanmasını sağlayacağı, meleklerin, enbiyanın orada hazır bulunduğu vb. çok sayıda rivayet ile bu ziyaret, Şiî kültürün vazgeçilmez pratikleri arasında yer almıştır. ${ }^{19}$ Ancak ziyaret alanındaki klasik dönemin ilk müstakil eseri olan Kâmilu'z-Ziyârât'ta imamların kabirlerinin ziyaretleri yanında Şaban ayının ortası ve Receb aylarına özel çeşitli ziyaret günlerinden bahsedilmişken, Safer ayının yirminci gününe denk gelen Erbaîn'e özel bir ziyaretin kutsiyetine yer verilmemiş olması oldukça ilginçtir. ${ }^{20}$ Ancak söz konusu eserde kırk sayısına verilen özel önemin ve bu konuya yapılan bir vurgunun sonucu olsa gerek, "gökyüzünün Hüseyin'in ölümünden sonra kırk gün boyunca kan ağladığı, yeryüzünün kapkara olduğu, güneşin nurunu söndürdüğü vb.” şeklinde bir rivayete yer verildiği görülmektedir. ${ }^{21}$

12 - İran'da y1l boyu kutlanan gün ve gecelere dair geniş bilgi için bk. Habip Demir, “Günümüz İran Şiiliğinde Kutsal Gün ve Geceler", e-Makalat Mezhep Araştırmaları Dergisi 10/2 (2017), 315-351.

13 - Abdulhüseyin Nîşâbûrî, Takvîm-i Şîa (Kum: İntişârât-1 Delîl-i Mâ, 1391/2012), 68.

14 - Muhammed Ali Kâdi Tabatabaî, Tahkîk der bâre-i Evvel-i Erbâin-i Hazret-i Seyyidu'ş-Şuhedâ (a.s.) (Tehran: Vezâret-i Ferheng ve İrşâd-i İslâmî, 1390/2011), 2; Afşin Mutkî - Rıza Mollahüseynî Erdekânî, "Tebyîn-i Câygâh ve Nakş-1 Erbaîn der İrtikâ-yı Prestij-i Jeopolitîkî-yi Teşeyyu’”, Nigerişhâ-yı Nov der Coğrafyâ-yı İnsânî 12/3 (1399/2020), 100.

15 - Abdülkerim Pâknüyâ, "Erbaîn der Ferheng-i Ehl-i Beyt”, Mübelligân, (ts.), 21-33; Seyyid Muhammed Muhsin Hüseynî Tahrani, Erbaîn der Ferheng-i Şîa (Kum: Arş-1 Endîşe, 1426/2005).

16 - Mutkî - Erdekânî, “Tebyîn-i Câygâh ve Nakş-1 Erbaîn der İrtikâ-yı Prestij-i Jeopolitîkî-yi Teşeyyu’”, 99.

17 - "Pejûhişî der Erbaîn-i Hüseynî Kısmet-i Evvel” (Erişim 23 Ocak 2020).

18 - Hüseynî Tahrani, Erbaîn der Ferheng-i Şîa, 75.

19 - Ebu'l-Kâsım Cafer b. Muhammed İbn Kûleveyh el-Kummî, Kâmilu'z-Ziyârât, thk. Şeyh Cevad el-Kayyûmî (Kum: Sitâre, 1429/2008), 216-433.

20 - İbn Kûleveyh el-Kummî, Kâmilu'z-Ziyârât, 323-341.

21 - İbn Kûleveyh el-Kummî, Kâmilu’z-Ziyârât, 167. 
Erbaîn gününe özel bir ziyaret ve ritüel kültürünün ilk dönemde ortaya çıkmamış olmasına rağmen, bu günde yaşandığı düşünülen ve Şiî gelenek açısından önemli sayılabilecek bazı olaylara değinmek gerekmektedir. Başta Taberî (ö. 310/923) olmak üzere ilk dönem İslam Tarihi kaynaklarında Safer ayının yirminci gününde gerçekleşen herhangi bir olaya dair rivayet yer almamaktadır. Müstakil olarak Erbaîn gününün önemine ilk değinen müelliflerden olan Şeyh Müfid (ö. 413/1022), Mesâru'ş-Şîa adlı eserinde Safer ayının yirmisinde gerçekleşen iki önemli olaya değinmiştir. Ona göre, İmam Hüseyin'in ailesi bu günde Şam'dan Medine'ye hareket etmiş ve yine sahabeden Câbir b. Abdullah, aynı gün Hüseyin'in kabrini ziyaret etmiştir. ${ }^{22}$ Bîrûnî (ö. 440/1048) ise Safer ayının yirmisinde Hz. Hüseyin'in başının bedenine iade edilerek defnedildiğini ve Şam'dan gelen ehli beyte mensup bir grubun onun kabrini ziyaret ettiğini ifade etmektedir. ${ }^{23}$

Erbaîn günü Hüseyin'in kabrinin ziyaret edilmesinin önemine dair ilk rivayetin yine Şeyh Müfîd tarafından aktarıldığı görülmektedir. Onun "Erbaîn Ziyaretinin Fazileti Hakkında" başlığıyla verdiği rivayete göre Hasan el-Askerî’nin, "Müminin alâmeti beştir: günlük 51 rekat namaz [farz, nafile ve gece namazı], erbain ziyareti, sağ ele yüzük takmak, secdeden alnı kaldırmak ve [namazda] Bismillahirrahmanirrahimi yüksek sesle söylemek." dediği aktarılmıştır. ${ }^{24}$ Bu rivayetin, sonraki kaynaklara da aynı şekilde geçtiği görülmektedir. ${ }^{25}$

Erbaîn ziyaretinden bahseden ilk kişi Şeyh Müfîd olmasına rağmen bu konuyu çeşitli yönleriyle müstakil hale getirip vurgulayan ise, onun öğrencisi Şeyh Tûsî (ö. 460/1067) olmuştur. Şeyh Tûsî’nin, Şiî geleneğin dua kitaplarının şaheseri olarak kabul edilen Misbâhu'l-Müteheccid adlı eserinde ${ }^{26}$ konuya özel bir başlık açtığı görülmektedir. Yine Şeyh Tûsî'nin bununla bağlantılı rivayetleri Kütübü Erba 'a arasında yer alan eserinde de naklettiği görülmektedir. ${ }^{27}$ Şeyh Tûsî, eserinde Erbaîn günü ile ilgili olarak şu ifadelere yer vermektedir:

“Safer'in 20'si yani Erbaîn, Imam Hüseyin'in haremi yani esir kervanı, Şam'dan Medine'ye hareket etmiştir. Yine bugün Resûlullah'ın sahabesi Câbir b. Abdullah b. Harâm el-Ensârî (r.a.), Medine'den Kerbelâ'ya gelmiş ve burada Ebî Abdillah'in (a.s.) kabrini ziyaret etmiştir. O, onun kabrini ziyaret eden ilk kişidir. Bugün onu ziyaret etmek müstehabtır. Bu ziyaret “Ziyâretü'l-Erbaîn” olarak anılır. ’28

Şeyh Tûsî, bunun ardından Erbaîn ziyaretinde okunacak özel bir duayı Câfer es-Sâdık’tan nakleder. ${ }^{29}$ Bu dua, halen ziyaret kitaplarında ve dua mecmualarında yer alan metinlere kaynaklık eden rivayet olarak öne çıkmaktadır.

Erbaîn günü gerçekleşen olaylarla ilgili rivayette dikkat çeken önemli noktalardan biri, Kerbelâ olay1 sonrasında Şam'a götürülen esirlerin dönüşü meselesidir. İbn Tâvûs (ö. 664/1266), dua türünde klasik olarak kabul edilen İkbâlu'l-A ‘mâl adlı eserinde, Şeyh Tûsî’nin, Şam'da bulunan esirlerin Medîne'ye doğru

22 - Muhammed b. Muhammed Şeyh Müfid, Mesâru'ş-Şîa, thk. Mehdî Necef (Kum: Dâru'l-Müfîd, 1413/1992), 46.

23 - Ebû Reyhan el-Bîrûnî, Maziden Kalanlar (el-Âsâr el-Bâkiye), çev. D. Ahsen Batur (İstanbul: Selenge Yayınları, 2011 ), 352.

24 - Muhammed b. Muhammed Şeyh Müfid, Kitâbu'l-Mezâr (Menâsiku'l-Mezâr) (Kum: Kongre-i Cihânî-yi Hezâre-i Şeyh Müfid, 1413/1992), 53.

25 - Bu kaynaklardan bazıları için bk. Muhammed b. Ahmed Fettâl Nîşâbûrî, Ravzatu'l-Vâizîn ve Basîretü'l-Müteazzîn (Tehran: Neşrenî, 1366/1987), 1/195; Muhammed b. Cafer İbn Meşhedî, el-Mezâru'l-Kebîr, thk. Cevâd Kayyûmî İsfehânî (Kum: Defter-i İntişârât-i İslâmî, 1419/1988), 352; Muhammed b. Hasen Şeyh Hür Âmilî, Vesâilu'ş-Şîa (Kum: Müessesetü Âli Beyt Aleyhimusselâm, 1409/1988), 14/478; Muhammed Bâkır Meclisî, Bihâru'l-Envâr (Beyrut: Dâru İhyâ-i’t-Turâsi'l-Arabî, 1403/1982), 82/75.

26 - Resûl Ca’ feriyân, “Şîa’da Dua Edebiyatı”, çev. Habip Demir, Iğdır Üniversitesi İlahiyat Fakültesi Dergisi 6 (2015), 227.

27 - Muhammed b. el-Hasen Şeyh Tûsî, Tehzîbu'l-Ahkâm, thk. Hasan el-Mûsevî Horasan (Tehran: Dâru'l-Kütübi'l-İslâmiyye, 1407/1986), 6/52.

28 - Muhammed b. el-Hasen Şeyh Tûsî, Misbâhu'l-Müteheccid ve Silâhu'l-Mute'abbid (Beyrut: Müessesetu F1khi'ş-Şîa, 1411/1990), 2/787-788; Şeyh Hür Âmilî, Vesâilu'ş-Şîa, 14/489-490.

29 - Şeyh Tûsî, Misbâhu'l-Müteheccid, 2/788-790; Şeyh Tûsî, Tehzîbu'l-Ahkâm, 6/113; İbn Meşhedî, el-Mezâru'l-Kebîr, 514; Muhammed b. Mekkî Şehîd-i Evvel, el-Mezâr (Kum: Medrese-i İmam Mehdî Aleyhisselâm, 1410/1989), 185-188; İbrahim b. Ali Âmilî Kef'amî, el-Misbâh li’l-Kef'amî (Kum: Dâru'r-Razî, 1405/1984), 489-490; Hac1 Şeyh Abbas Kummî, Mefâtîhu'l-Cinân (Kum: İntişârât-1 Âyîn-i Dâniş, 1386/2007), 776-778. 
gittikleri yönündeki rivayetini naklettikten sonra bu esirlerin Medine'den önce Kerbelâ'ya doğru gittikleri yönünde de farklı bir rivayet olduğunu kaydeder ve ilgili rivayeti naklettikten sonra bunun aklen mümkün olamayacağını açıklar. ${ }^{30}$ İbn Tâvûs'un eserinde esirlerin Medîne'den önce Kerbelâ'ya gidip Erbaîn gününde Hüseyin'in kabrini ziyaret etmiş olduğu yönündeki zayıf rivayet, günümüze kadar Şiî müelliflerin tartıştığı meselelerden biri haline gelmiştir. Abbas Kummî, Müntehiye'l-Âmal'da Kerbelâ olayı sonrasında geride kalan esirlerin önce Kûfe, ardından Şam'a doğru olan yolculukları hakkında detaylı bilgi vermektedir. ${ }^{31}$ Ancak İbn Tâvûs'un rivayetini aktardıktan sonra, esirlerin Şam'dan Medine'ye doğru hareket ettiklerini vurgular ve onların haklı olarak böyle bir hengamede Şam'dan Kerbelâ'ya dönmelerinin mümkün olamayacağınıbelirtir. ${ }^{32}$

Kerbelâ esirlerinin, Safer ayının yirmisinde, yani Erbaîn günü, Hz. Hüseyin'in kabrine yolculuk etmediklerini iddia edenlerin fazla olması, bununla ilgili eleştirilere cevap vermek üzere müstakil eserler yazılmasına neden olmuştur. Çağdaş yazarlardan Muhammed Tabatabâî, konuyu irdelediği hacimli eserinde, Kerbelâ esirlerinin Şam'dan sonra Hüseyin'in kabrini ziyaret ettiklerini çok sayıda rivayete dayandırmaya çalışmış, böyle bir iddianın aksinin tarih kitaplarında doğrulanamadığını belirtmiştir. ${ }^{33}$ Onunla aynı görüşü savunan başka yazarlar da mevcuttur. ${ }^{34}$ Ancak Tabatabâî'nin halen ses getirmeye devam eden eseri hakkında Ca'feriyân, oldukça hacimli olmasına rağmen bu eserin bu konuda tatmin edici bir sonuca ulaşamadığ1 yönünde eleştiriler yöneltmiştir. ${ }^{35}$ Yine böyle bir konunun kesin olmadığını vurgulamak üzere müstakil çalışmalar da halen yayınlanmaya devam etmektedir. ${ }^{36}$ Dolayısıyla Şiî gelenekte Erbaîn gününe kazandırılan anlamın takviyesi amaçlı olduğunu düşündüğümüz bu iddialar, bizzat Şiî yazarlar tarafından dahi üzerinde uzlaşılan bir konu olmaktan uzak durumdadır.

Erbaîn gününe özel zikredilen konulardan birisi de Câbir b. Abdullah'1n Hüseyin'in kabrini ziyaret etmesidir. Câbir'in Kerbelâ'yı Erbaîn günündeki ziyareti hakkındaki en detaylı bilgileri, muahhar yazarlardan Muhammed Bâkır el-Meclisî (ö.1110/1698) vermektedir. Meclisî, konuya özel bir önem vermekte ve kendi dönemine kadarki tüm rivayetleri aktardığını iddia etmektedir. Buna göre, Câbir'in önemi, Kerbelâ olayından sonra burayı ilk ziyaret eden ve bu geleneği başlatan kişi olmasından kaynaklanmaktadır. ${ }^{37}$

Erbaîn gününü Şiî gelenekte farklı kılan özelliklerden olan ve bu günün "Reddu'r-Re's” olarak anılmasina sebep olan olaylardan biri de Hüseyin'in kesik başının bedenine iadesinin bu günde gerçekleşmiş olduğu yolundaki rivayetlerdir.38 Bu konudaki ilk rivayetlerden biri İbn A'sem Kûfî (ö. 320/932'den sonra) tarafindan dile getirilmiştir. O, Yezîd'in Kerbelâ'da öldürülen kişilerin başlarını Ali b. Hüseyin'e emanet ettiği ve 20 Safer günü başların bedenlerine iade edildiği bilgisini aktarır. Ancak İbn A'sem'in rivayetinde esirlerin yanlarında bulunan başlarla birlikte Kerbelâ'ya değil Medîne'ye yöneldiklerini ilave eder.39 Böylece bu iadenin başka bir Erbaîn günü olup olmadığı konusu muallakta kalmıştır. Bu konuda erken dönem müelliflerinden olan Şeyh Sadûk'un (ö. 381/991) da bir rivayet aktardığı görülmektedir. Şeyh Sadûk, Ali b. Hüseyin Zeynelâbidîn'in, babasının ve

30 - Ali b. Mûsâ İbn Tâvûs, İkbâlu'l-A'mâl (Tehran: Dâru'l-Kütübi'l-İslâmiyye, 1409/1988), 2/589.

31 - Şeyh Abbas Kummî, Müntehiye'l-Âmâl (Tehran: İntişârât-1 Peyâm-1 Âzâdî, 1390/2011), 1/643-723.

32 - Kummî, Müntehiye'l-Âmâl, 1/710-711.

33 - Tabatabaî, Tahkîk der bâre-i Evvel-i Erbâin-i Hazret-i Seyyidu'ş-Şuhedâ (a.s.), 20-45.

34 - Muhammed Fazı1, “Tahlîl Mebnâ-yı Tarîhî Erbaîn-i Hüseynî” (Erişim 15 Aralık 2020).

35 - Resûl Ca’feriyân, “Erbaîn-i İmam Hüseyin aleyhisselam (Yek Gozâriş-i İcmâlî)”, Makâlât-ı Târîhî (Tehran: Müesseset-i el-Hâdî, t.y.), 176-178.

36 - Muhammed Takî Sübhânîniyâ, “Tahkîkî der bâre-i Erbaîn-i Hüseynî”, Tarih-i İslam der Âyine-i Pejûhiş 6 (1384/2005).

37 - Meclisî, Bihâru'l-Envâr, 98/329-336.

38 - Fettâl Nîşâbûrî, Ravzatu'l-Vâizîn, 230; Muhammed b. Ali İbn Şehrâşûb, Menâkıbu Âl-i Ebî Tâlib Aleyhimu's-Selâm (Kum: Allâme, 1379/2000), 4/77; Meclisî, Bihâru'l-Envâr, 44/199.

39 - Ebû Muhammed Ahmed b. Ali İbn A’sem Kûfî, el-Fütûh, thk. Gulamrızâ Tabatabâî Mecd, çev. Muhammed b. Ahmed Müstevfî Herevî (Tehran: İntişârât-1 İlmî ve Ferhengî, 1386/2007), 916. Ancak bu bilginin eserin Farsça çevirisinde yer aldığını, Arapça (asıl) nüshasında olmadığını belirtmekte fayda vardır. Muhtemelen eserin 6./13. asırda yaşayan mütercimi bu rivayetleri eklemiş olmalıdır. 
Kerbelâ'da katledilen diğer fertlerin başlarını alarak Kerbelâ'da defnettiğini belirtir. ${ }^{40}$ Ancak bunun Safer ayının yirmisinde olup olmadığına dair bir bilgi vermez. İbn Şehrâşûb (ö. 588/1192) da Erbaîn ziyaretinin öneminin sebebi olarak Hüseyin'in başının Kerbelâ'da bedenine iadesi olduğunu zikreder. Ancak buna rağmen bu olayın Erbaîn günü mü yoksa başka bir gün mü olduğuna dair bir bilgi vermez. ${ }^{41}$

\section{KIMLIK INŞA EDICI BIR SEMBOL OLARAK ERBAIN ZIYARETi VE YÜRÜYÜŞÜ}

Modernleşme ile birlikte insanlar, yerel ve kısıtlayıcı her türlü kimliğin dışına çıkmaya, sosyal alana dair bütüncül kimliklerden uzaklaşıp daha fazla bireyselleşme, özgürleşme eğilimleri göstermeye başlamışlardır. Böyle bir ortamda özel olarak mezhepler tarafından sunulan daha dar kalıplı kimlik arayışlarına mesafeli bir tavrın giderek geliştiği gözlemlenmektedir. Ancak diğer yandan modernleşmenin getirdiği yalnızlık ve kimliksizlik gibi duyguların, insanları belli noktalarda birleştirecek üst kimliklere duyulan ihtiyacı artırdığını söylemek gerekmektedir. Bu bağlamda Şiîliğin, bir azınlık mezhebi olarak mezhep aidiyeti üzerinden mensuplarını konsolide edecek, belli noktalarda birleştirecek etkinlikleri önemsediği sıklıkla görülmektedir. Bu yönüyle Şiîliğin ritüel merkezli bir din anlayışı geliştirdiğini söylemek mümkündür. Kerbelâ ve onunla bağlantılı olan ritüeller de Şiîlik'te bir toplum yaratmanın, bu ritüellerde uygulanan ve topluma öğretilen gelenekler kanalıyla ahlakî bir yol çizmenin, böylece Şiî toplumunu bir arada tutmaya yarayacak bir "toplum" inşa etmenin aracı olarak görülmektedir. ${ }^{42}$

Şiîliğin, özellikle ulemanın ön plana çıktığg 19. yüzyıldan itibaren sistematik olarak kurumsal bir yapıya büründüğü, merci-i taklid makamının ortaya çıkmasıyla da toplumsal alandaki birtakım ritüellerin siyasi bir anlam kazanmaya doğru evrildiği görülmüştür. Bunun ilk tezahürlerini 1906 yılında İran' da gerçekleşen Meşrutiyet devriminde görmekteyiz. Devrime giden süreçte ulemanın da etkisiyle taziye merasimleri, adeta siyasi birliktelik ve kamuoyu oluşturmada bir araç olarak kullanılmıştır. ${ }^{43} \mathrm{Bu}$ merasimler, bir yandan devlet idarecilerinin törenlere katılarak toplumun nabzını tuttuğu, istek ve şikayetleri yerinde gördüğü sosyal bir platform iken, diğer yandan çeşitli yerlerden katılan geniş halk kitlelerinin belirli bir siyasî propaganda etrafında kamuoyu oluşturulabilmesi için potansiyel olarak görülmüştür. ${ }^{44}$

Şiîliğin toplumsal yönünü öne çıkaran çok sayıda merasimin yanında son dönemlerde Safer ayının yirminci gününe denk gelen Erbaîn'in siyasî ve sosyal bir işlev üzerinden Şiî kimliğini inşa etme görevi üstlendiği gözlenmektedir. Erbaîn'in böyle bir işlev kazandığı Şiî yazarlar tarafından da sıklıkla ifade edilmektedir. ${ }^{45}$ Erbaîn'i diğer merasimlere nazaran ön plana çıkaran ve onu bu derece farklı bir anlama büründüren en önemli faktörlerden birisi de Necef ve Kerbelâ şehirleri arasındaki mesafede geniş katılımla gerçekleştirilen yürüyüş etkinliğidir. Bu yürüyüş, günümüzde Şiîlerin en büyük merasimlerinden birisi haline gelmiştir. ${ }^{46}$ Öyle ki bu yürüyüş, sadece dinî anlam taşımaktan ziyade siyasi, sosyal, kültürel ve jeopolitik anlamları da kapsayan çeşitli boyutlara sahip bir etkinlik olarak ön plana çıkmıştır. ${ }^{47} 2015$ y1lında Iraklı resmî kanalların verdiği bilgiye göre bu yürüyüşe 26 milyon ziyaretçinin katılmış olması, ${ }^{48}$ yürüyüşün söz konusu anlamları

40 - Muhammed b. Ali Şeyh Sadûk, Emâlî (Tehran: Dâru'l-Kütübi'l-İslâmiyye, 1354/1975), 232.

41 - İbn Şehrâşûb, Menâkıbu Âl-i Ebî Tâlib Aleyhimu's-Selâm, 4/77.

42 - Seyyid Muhammed Musevî - Rıza Beyât, "Kâvişî der Âyîn-i Piyâderûy-i Erbaîn-i Hüseynî ve Esergozârî-yi Kârkerdhâ-yı İctimâi ve Siyâsi-yi Ân", Ferheng ve İrtibâtât 3/1 (1397/2018), 104.

43 - Emir Timur Refî̀ - Muhsin Ağahasanî, "Nakş-1 Âmûzehâ-yı Şî̂ (Ta’ziye ve Ezâdârî) der Nehzet-i Meşrûtiyyet”, Pejûhişnâme-i Târîh 11/41 (1394/2015), 4-6.

44 - Refî̀ - Ağahasanî, "Nakş-1 Âmûzehâ-yı Ş̂̂̂”, 8-12.

45 - Zahid Gaffârî Heşcîn - Muhammed Agâyî, "Piyâderûy-i Erbaîn-i Hüseyni ve Mesâbih-i Conbiş-i İctimâî”, Dâniş-i Siyâsî 14/1 (1397/2018), 17; Musevî - Beyât, “Kâvişî der Âyîn-i Piyâderûy-i Erbaîn-i Hüseynî̀, 104.

46 - Musevî - Beyât, "Kâvişî der Âyîn-i Piyâderûy-i Erbaîn-i Hüseynî”, 100.

47 - Musevî - Beyât, "Kâvişî der Âyîn-i Piyâderûy-i Erbaîn-i Hüseynî”, 94.

48 - Mutkî - Erdekânî, “Tebyîn-i Câygâh ve Nakş-1 Erbaîn der İrtikâ-yı Prestij-i Jeopolitîkî-yi Teşeyyu”, 106. Bu ziyaretçi rakamlarının gerçeği yansıtması zor görünmektedir. Nitekim, ziyaretçi sayılarını bildiren makam, Kerbelâ'daki türbenin resmi organıdır. Ancak bu rakamların nasıl elde edildiği ve böyle bir istatistiğin hangi kriterlere göre tespit edildiği bilinmemektedir. 2020 y1lı için 14 milyon ziyaretçiden bahsedilmektedir. Bk. "Müşâreket-i 14 Milyon Zâir der Merâsim-i Erbaîn-i Hüseynî" 
da beraberinde getiren oldukça büyük bir organizasyon haline geldiğini göstermektedir.

Şiî gelenekte, başta Hz. Hüseyin olmak üzere imamların kabirlerine yürüyerek gitmenin sevabı hakkında çeşitli rivayetler yer almaktadır. ${ }^{49}$ Hüseyin'in ziyaretine yürüyerek gidenlerin her bir adımının sevap olduğu, ${ }^{50} \mathrm{~Hz}$. Ali'nin ziyaretine yürüyerek gidenlerin her bir adımına iki hac ve iki umre sevabı verileceği şeklindeki rivayetler, ilk dönemlerden itibaren Şiî gelenekte yürüyüşle ilgili motiflerin yer aldığını göstermektedir. ${ }^{51}$ Ancak Şiî tarihinde Erbaîn'e özel böyle bir yürüyüşün erken dönemlere uzanan tarihsel bir geçmişinin olmadığı bilinmektedir. Her ne kadar günümüz Şiî eserlerinde bu şekilde yürüyerek ziyaretin, imamlar zamanında mevcut olduğu kaydedilmekteyse de ${ }^{52}$ Erbaîn'e özel yürüyüşün yakın zamanlara kadar yalnızca Irak Şiîlerinin yerel sâiklerle gerçekleştirdikleri bir faaliyet olduğu, uluslararası bir boyuta ulaşmasının son dönemlere denk geldiği görülmektedir. ${ }^{53}$ İranlı Siyaset Bilimcilerden Musa Necefî de geçmişte böyle bir yürüyüşün ve ziyaretin olduğunu kabul etmekle birlikte mevcut düzen ve ölçüde yapılan şeyin modern bir olgu olduğunu ifade etmekte ve bunu Batı medeniyeti karşısında İslam medeniyetinin kendine özgü bir şekil alma çabası olarak betimlemektedir. ${ }^{54}$ Nitekim, Şeyh Murtazâ Ensarî’nin (ö. 1864) Irak'ta merci-i taklîd olarak ön plana çıktığı dönemde uygulanan, ancak onun ölümüyle unutulan bu yürüyüşün, onun öğrencisi Muhaddis Nurî (ö. 1902) tarafından yeniden canlandırıldığı ifade edilmektedir. ${ }^{55}$ Birinci Dünya Savaşı'nın ardından kurulan yeni siyasî ortamla birlikte de devam eden bu etkinlik, yüzyılın ikinci yarısından itibaren daha geniş kitlelerce gerçekleştirilmeye başlanmıştır. Örneğin, 1967 yılında basılan Edebu't-Taff adlı esere göre Erbaîn'de yapılan bu merasimler ve toplanan kalabalığın bir milyon kişiyi aştı̆̆ 1 belirtilerek Hac sırasında Mekke'de oluşan kalabalığa benzetilmiştir. ${ }^{56}$

Irak'ta Baas'ın iktidara gelmesiyle birlikte yasaklanan bu yürüyüşler, siyasi sıkıntıları da beraberinde getirmiştir. Örneğin, 1977 'de 30 bin kişilik bir gruba ordunun müdahale etmesi sonucunda çok sayıda kişinin yaşamını yitirdiği kaydedilmiştir. ${ }^{57}$ Tarihe "Kanlı Erbaîn" olarak geçen bu tören, Şiî toplumsal bünyede önemli bir yara açmıştır. ${ }^{58}$ Dönemin ünlü müçtehitleri Muhammed Bâkır Sadr ve Muhammed Bâkır Hekîm'in böyle bir ortamda bu yürüyüşün ve burada elde edilen mücadelenin kutsallığına yönelik vurguları, Erbaîn'in zihinlerde daha da kökleşmesini sağlamıştır. 2003 yılında Baas iktidarının ortadan kalkmasıyla, Şiîlerin toplumsal ve siyasal alandaki görünürlükleri oldukça artmış ve yeni bir döneme girilmiştir. Böyle bir ortamda Erbaîn yürüyüşü, her yıl daha ihtişamlı bir şekilde gerçekleştirilmeye, yeni olgularla ve yorumlarla genişletilmeye devam etmiştir.

Iraklılar, Erbaîn gününe birkaç gün kala, geçmişten bu yana yaptıkları gibi kendi yerleşim yerlerinden Kerbelâ'ya doğru yürürken, başta İranlılar olmak üzere diğer milletlerden katılımcılar, Necef'ten Kerbelâ'ya doğru yürümektedir. Bu iki şehir arasındaki yaklaşık 80 km'lik mesafede 50 m'de bir olmak üzere 1452 adet sütun bulunmakta, böylece yürüyüşün düzeni sağlanarak toplamda 1-2 günde yürüyüş tamamlanmaktadır. Yürüyüşün sorunsuz bir şekilde devamı ve ziyaretçilere iaşe sağlamak için ise "Mevkib" adı verilen yerler

(Erişim 12 Aralık 2020). Ancak Korona virüsü nedeniyle İran sınırının kapalı olması da dikkate alınırsa ziyaretçi sayısının böyle bir rakama ulaşması en azından bu yıl için mümkün görünmemektedir. Bu konuda söylenen rakamların gerçeği yansıtmadığı ile ilgili bir analiz için bk. "Âyâ Pes ez İctimâ' '14 Milyonî Erbaîn’ Âmâr-1 Fovtîhâ-i Korona der Kerbelâ ve Necef Sıfr Şodeend?” (Erişim 12 Aralık 2020).

49 - Hatta Hür Âmili Vesâilu'ş-Şîa adlı eserinin bir bölümünü "Bâbu İstihbâbi’l-Meşyi ilâ Ziyâreti'l-Hüseyin ve Gayrihi (Hüseyin ve Diğerlerinin Ziyaretlerine Yürüyerek Gitmenin Tercih Edilmesi)” başlığına yer vermektedir. Şeyh Hür Âmilî, Vesâilu'ş-Şîa, 14/439-442.

50 - İbn Kûleveyh el-Kummî, Kâmilu'z-Ziyârât, 252-259.

51 - Şeyh Hür Âmilî, Vesâilu'ş-Şî̀a, 14/1404.

52 - Tabatabaî, Tahkîk der bâre-i Evvel-i Erbâin-i Hazret-i Seyyidu'ş-Şuhedâ (a.s.), 34.

53 - Mutkî - Erdekânî, “Tebyîn-i Câygâh ve Nakş-1 Erbaîn der İrtikâ-yı Prestij-i Jeopolitîkî-yi Teşeyyu””, 105.

54 - "Râhpeymâyî-yi Erbaîn Hüviyyet-i İnkılâb-1 İslâmî Est” (Erişim 23 Ocak 2021).

55 - Muhammed Cevad Durûdiyân, “Menzer-i Ma’nevî Rûydâd-1 Piyâderûy-i Erbaîn-i Hüseynî”, Mecelle-i Menzer 10/45 (1397/2018), 59.

56 - Heşcîn - Agâyî, "Piyâderûy-i Erbaîn-i Hüseyni”, 10.

57 - Hüseyinali Arabî, "Piyâderûy-i Erbaîn-i Hüseynî: Câygâh ve Kârkerdhâ”, Marifet 28/7 (1398/2019), 49-50.

58 - Durûdiyân, “Menzer-i Ma’nevî Rûydâd-1 Piyâderûy-i Erbaîn-i Hüseynî”, 59. 
yapılmıştır. Yol boyunca taklit mercilerinin ofisleri tarafindan oluşturulmuş bu kulübelerde Şiî düşüncenin çeşitli yönlerine dair konuşmalar, broşürler ve etkinliklerle yürüyüş boyunca ciddi bir propaganda yapılmaktadır. Yol üzerinde "Hûsehân̂̂" adı verilen kasidelerle birlikte ziyaretçilere kahramanlık ve cesaret temalı şiirler okunup kalabalıkların tekrarlaması sağlanmakta ve böylece yürüyüşün sosyal bir hareket görünümü kazanması amaçlanmaktadır. ${ }^{59} \mathrm{Bu}$ bağlamda Erbaîn yürüyüşünün bir devlet organizasyonu değil sosyal bir hareket olarak görünmesi çabası, Şiîler tarafindan üzerinde önemle vurgu yapılan bir meseledir. ${ }^{60} \mathrm{Bu}$ yönüyle faaliyet, kültürel kimliğin korunması ve özellikle gençler üzerinde bırakılan derin tesirlerinin sonucu olarak Şî̂ kültürün gelecek nesillere aktarılmasında önemli bir görev ifa etmektedir. ${ }^{61}$ Kerbelâ merasimlerinde Hz. Hüseyin'in katledilmesi hatırlanarak keder ve üzüntü temaları ön plana çıkartılırken, Erbaîn'in bunun ötesinde anlamlar kazandığı görülmektedir. Bu yürüyüşün, insanlar üzerinde bir arınma psikolojisi oluşturduğu, "herhangi bir devletin organizasyonu olmaması nedeniyle" insanların kendi arzularıyla böyle bir arınma ihtiyacına cevap vermek üzere bu etkinliklere katıldığ 1 vurgulanmaktadır. ${ }^{62}$

Erbaîn yürüyüşü, zaman zaman çeşitli provokatif girişimlere sahne olsa da Şiîlerin, burada insanların kendilerini emniyette hissettiklerini, farklı kültürlerden gelen ziyaretçilerin, bu uzun yürüyüş sırasında tanışıp kültürlerarası irtibatların arttığını vurguladıkları görülmektedir. Bu yürüyüşs sırasında herkesin birbirine bir şeyler ikram etme telaşı içine girdiği, böylece ziyaretçilerin bu ritüel sırasında hiçbir mali yüke uğramadan ${ }^{63}$ misafirperverlikle karşılandıkları vurgusu, yürüyüşün sosyal yönünün ön plana çıkarıldığını göstermektedir. ${ }^{64}$ Böylece bu yürüyüş, Şîa'nın kendine mahsus bir toplum olma yolunda önemli bir işlev üstlenmektedir. En küçügünden en büyüğüne kadar çeşitli yaşlardan Şiîler, böyle bir etkinlikte gönüllü olarak iş bölümü içerisinde görevler üstlenmekte, bu görevler onların sosyalleşmesine imkân sağlamaktadır. ${ }^{65}$ Hatta daha da ileri giderek bu yönüyle yürüyüşü, Şiî toplumunu aşarak evrensel boyutta İslam medeniyetinin yeniden ihya edilmesinde bir araç olarak tanımlayan Şiî yazarlar da bulunmaktadır. ${ }^{66}$

Buraya kadar anlatılanlardan yola çıkarak, Erbaîn günü yapılan yürüyüş ve etkinliklerin Şiîlik merkezli bir propaganda faaliyeti olduğu gerçeği göz ardı edilerek yürüyüşün sadece Şiîler açısından değil, dünya Müslümanlarının da sömürgeci güçlere karşı verdiği birlik ve beraberlik mesajı olduğu ifade edilmektedir. ${ }^{67}$ Aslında burada tüm Müslümanların birlik ve beraberliğinden kastın, ortak değerler üzerinde bir birleşmeden ziyade Şiî düşünce eksenli bir birleşme olduğu dikkatlerden kaçmamaktadır. Bu bağlamda "Hep birlikte Allah'ın ipine sarılın" ayetindeki Allah'ın ipinin, Ehl-i Beyt soyu olarak yorumlandığı Şiî düşüncede bilinen bir olgudur. Bu noktada Erbaîn'de çeşitli millet ve kültürlerden gelen insanların yürüyüş esnasında taşıdıkları farklılıkları bir kenara bırakarak bütünleştiklerinin ifade edilerek bu durumun, ayetin manasının tecellilerinden biri olarak yorumlanması, ${ }^{68}$ burada kastedilen birliğin niteliğini göstermesi açısından dikkate değer bir yaklaşımdır. Böyle bir yaklaşımın en bariz izleri, 1979'da gerçekleşen İslam Devrimi'nin ardından Ayetullah Humeynî'nin "Vahdet” olarak nitelendirdiği ve milliyet gözetmeksizin dünyadaki tüm Müslümanların ortak hareket edip bir bütün haline gelmelerini amaçlayan politikalarını akla getirmektedir.

59 - Heşcîn - Agâyî, "Piyâderûy-i Erbaîn-i Hüseyni”, 14.

60 - Musevî - Beyât, "Kâvişî der Âyîn-i Piyâderûy-i Erbaîn-i Hüseynî”, 101.

61 - Musevî - Beyât, "Kâvişî der Âyîn-i Piyâderûy-i Erbaîn-i Hüseynî”, 102.

62 - "Râhpeymâyî-yi Erbaîn Hüviyyet-i İnkılâb-1 İslâmî Est".

63 - Bu konuda İran'da bulunduğum zaman zarfında ziyaretçilerin Erbaîn'de para harcamadıklarını duyunca şaşırmış ve bununla ilgili çeşitli sohbetler gerçekleştirmiştim. Birçok kişinin bu durumu, böyle bir tavır ile Hac sırasında "Vehhâbîlerin" maddî kaygılar gözeterek hacıları ticari bir araç olarak görmeleri karşısında Şiîlerin ne kadar erdemli olduğuna bir delil olarak sunduğu gözlemlenmiştir.

64 - Durûdiyân, “Menzer-i Ma’nevî Rûydâd-1 Piyâderûy-i Erbaîn-i Hüseynî”, 60-62.

65 - Arabî, "Piyâderûy-i Erbaîn-i Hüseynî”, 50; Muhammed Hâkî - Seyyid Kâsım Hüseynî, "Nakş-1 Râhpeymâyî-yi Erbaîn-i Hüseynî der İcâd-1 Temeddünnevîn-i İslâmî”, Pejuhişnâme-i Meârif-i Hüseynî 5/19 (1399/2020), 102-103.

66 - Hâkî - Hüseynî, "Nakş-1 Râhpeymâyî-yi Erbaîn-i Hüseynî”, 94.

67 - Mustafa Cemâlî, "Nakş-1 Erbaîn der Muhendisi-yi Temeddün-i İslâmî”, Mutalaât-ı Mescid ve Mehdeviyet 2 (1395/2016), 43; Mesud Ensârî, "Erbaîn-i Hüseynî, Cilve-i İktidâr-1 Ümmet-i İslâmî ve Câvidânegî-yi Peyâm-1 Âşûrâ Est”, IRNA (Erişim 24 Ocak 2021).

68 - Cemâlî, "Nakş-1 Erbaîn”, 41. 
Humeynî’nin en büyük ideallerinden biri olan İslam ümmeti oluşturma gayretleri, bu vahdetin siyasi, iktisadi ve kültürel anlamda birlik sağlanarak gerçekleştirileceği düşüncesinden yola çıkmaktadır. ${ }^{69}$ İran'ın halen liderliğini üstelenen Ali Hamaneî, 1987 yılında yaptığı bir konuşmada Erbaîn'in Şiîler açısından birlik ve beraberlik işareti bir nevi mahşer yerini andıran bir simge olduğundan bahsetmektedir. ${ }^{70}$ Aynı konuşmalarını her yıl Erbaîn gününde benzeri ifadelerle tekrarlamaktadır. Hamaneî, Erbaîn gününün birçok bakımdan bir başlangıç noktası olarak kabul edilmesi gerektiğini ifade etmektedir. ${ }^{71}$ Dolayısıyla Erbaîn ritüelinin bu anlamda İslam inkılabının hedefinin milletlerarası boyutuna katkı yaptığı, böylece aslında evrensel bir söyleme sahip olduğu sıklıkla vurgulanmaktadır. ${ }^{72}$

Şiî çevrelerde Erbaîn'in, yalnızca Hüseyin'in ziyareti olarak sınırlandırılamayacağı, aynı zamanda seküler Batı medeniyeti karşısında İslâmî bir modelin mümkün olduğu, yerli unsurlarla desteklenen ve İslam'ın kucaklayıcı yönünü vurgulayan, tamamen İslâmî unsurlarla bezeli bir faaliyet olduğu sıklıkla vurgulanarak, bu faaliyet üzerinden yeni bir ümmet ve nihayetinde yeni bir medeniyet oluşturmanın mümkün olduğu dile getirilmektedir. ${ }^{73}$ Yürüyüşe katılanlar arasında yalnızca Şiîler değil, Sünnîler, Hristiyanlar, Yezîdîler, Zerdüştler gibi çeşitli tabakalardan insanların yer aldığının iddia edilmesinin Erbaîn'i, dinler ve mezhepler üstü bir hüviyete büründürdüğü kabul edilmektedir. ${ }^{74}$ Farklı ülkelerden ve inanç gruplarından gelen ziyaretçiler arasında kültürel işbirliğinin geliştirilmesi, kalacak yer ve yiyecek giderlerinin yerel imkanlarla karşılanması, milletler arasında yakınlık ve duygu birliğinin artmasına katkıda bulunduğu dile getirilmektedir. ${ }^{75}$

Erbaîn'in, sosyal ve kültürel olarak çeşitli anlamlara büründürülmesinin yanında onun son yıllarda üstlendiği en önemli işlevlerden birisi de giderek siyasî boyut kazanmasıdır. Bu yürüyüşün siyasî boyut kazanması, özellikle 2011 sonrası bölgede başlayan Arap Baharının Şiî dünyadaki izdüşümü olarak da okunabilmektedir. Erbaîn' in "İslamî Uyanış” kavramıyla iç içe bir anlam kazanarak simge haline getirilmeye başlandığı gözlenmektedir. Şiî yazarların söylemlerinde Erbaîn'in tarih ve şimdi arasında kurulan bir köprü görevi üstlenmeye doğru evrildiği, Kûfelilerin Hüseyin'i Kerbelâ'da yalnız bırakmalarının ardından Erbaîn'le birlikte zihinlerinin açıldığ 1 , cihad, şehadet ve diriliş kavramlarının anlam kazandığı, zaman ve mekan üstü bir nitelikte, çok sayıda Müslümanın sömürgeci güçler karşısında dimdik duruşlarının siyasi bir sembolü ve Şî̂lerin kendileri dışındaki zalim yönetimler karşısında bir karşı duruşu olarak görülmektedir. ${ }^{76}$ Bu yürüyüşe katılanların tamamının özgürlük ve kurtuluş temalı sloganlar attıkları, tıpkı Hüseyin'in zulüm ve zalimden kurtulduğu gibi Şiîlerin de zalim düzenden kurtulmaları için bir haykırış olduğu, Şiîlerin tüm dünyaya birlikte verdikleri, Şiî coğrafyasının sınırlarını aşan bir nevi gövde gösterisi olduğu vurgusu, bu faaliyetin kazandığı anlamlar arasında yer almaktadır. ${ }^{77}$

69 - Ali Ahmedî, “Delâlethâ-yı Râhbordî-yi İrtibâtât Miyânferhengî berâ-yı Hemgirâyî-yi İslâmî bâ Te’kîd ber Râhpeymâyi-yi Erbâin”, Nâme-i Ferheng ve Irtibâtât 3/1 (1397/2018), 27; İran’da Devrim sonrasında yapılan bu tür faaliyler ve yaklaşım tarzları hakkında detaylı bir analiz için bk. Cemil Hakyemez, "Mezhepleri Yakınlaştırma (Takrîbü'l-Mezâhib) Çalışmalarının Değerlendirilmesi”, İslâmî Araştırmalar 29/2 (2018), 300 vd.

70 - “İmam Hâmaneî: Be Şiîyân yâd Dâdend İncâ Mahall-i İctimâ-i Şomâst” (Erişim 02 Ocak 2021).

71 - Onun Erbaîn hakkındaki konuşmalarından bazı örnekler için bk. "Erbaîn-i Hüseynî Mîâdgâh-1 Şîeyân ve Kongre-i Azîm-i Cihânî” (Erişim 23 Ocak 2021); Ali Hamaneî, "Hamâse-i Râhpeymâyi-i Erbaîn” (Erişim 23 Ocak 2021).

72 - "Erbaîn Mukaddime-i Mülk-i Mehdevî Est” (Erişim 23 Ocak 2021).

73 - Seyyid Mecid İmâmî - Hâdî Gryâsî, "Hemgirâyî-i Temeddünî der Tarîk-i Ziyâret; Bâ Te’kîd ber Piyâderû-yi Ziyâret-i Erbaîn", Do Faslnâme-i İlmî Pejûhişî Dîn ve Siyâset-i Ferhengî 9 (1396/2017), 128-129; Muhsin Pervîş, "Berresî-yi Zerfiyethâ-y1 Temeddünsâzî der Cihân-1 İslam ve Bâ Tekye ber Piyâderûy-i Erbaîn”, Temeddün-i İslamî ve Dînpejûhî 1/2 (1398/2019), 10; “Temeddün-i İslâmî Nâşî ez Ferheng-i Âşûrâ ve Erbaîn Mâye-i Tahakkuk-i Ân Est” (Erişim 23 Ocak 2021).

74 - Pervîş, "Piyâderûy-i Erbaîn”, 44; Mutkî - Erdekânî, “Tebyîn-i Câygâh ve Nakş-1 Erbaîn der İrtikâ-yı Prestij-i Jeopolitîkî-yi Teşeyyu”,, 107; Hâkî - Hüseynî, "Nakş-1 Râhpeymâyî-yi Erbaîn-i Hüseynî”, 108. Farklı din ve mezheplerden kişilerin yürüyüşlere katıldığ 1 hakkında elimizde yeterli bilgi bulunmamaktadır. Bu konudaki iddiaların, yürüyüşlerin evrensel nitelik kazanması adına Şiî yazarlar tarafından dile getirildiği unutulmamalıdır.

75 - Ahmedî, "Râhpeymâyi-yi Erbâin", 32-34.

76 - Pervîş, "Piyâderûy-i Erbaîn", 47-48.

77 - Pervîş, "Piyâderûy-i Erbaîn”, 47-48; Ensârî, "Erbaîn-i Hüseynî, Cilve-i İktidâr-1 Ümmet-i İslâmî ve Câvidânegî-yi Peyâm-1 Âşûrâ Est”. 
Günümüz İsnâaşerî Şiîliğginde Erbaîn'in en önemli işlevlerinden birisi de Şiî gelenek tarafindan güçlü bir şekilde vurgulanan Mehdî inancının somut bir tezahürü olmasıdır. Mehdî beklentisinin aynı zamanda siyasî bir anlamı olduğu bilinen bir olgudur. Bu bağlamda Erbaîn'in mehdînin zuhurunun bir provası olduğuna ve bu inancı takviye edici bir işlev üstlendiğine de işaret edilmektedir. Burada milyonlarca Şiînin ortak bir gaye etrafında bir araya gelmesi, "İslamî Uyanış" olarak adlandırılan olgunun somut bir göstergesi olduğu ve böylece toplumu mehdînin zuhuruna hazırlama görevini oldukça başarılı bir şekilde canlı tuttuğu dile getirilmektedir. ${ }^{78}$

Şiî çevrelerde her ne kadar bu faaliyetin devlet destekli olmadığı, halk merkezli sivil bir inisiyatif olduğu vurgusu hâkim olsa da bunun gerçeği yansıtmadığı, İran' da son yıllarda yayınlanan çalışmalarla dile getirilmektedir. Böyle bir faaliyetin dünya üzerindeki Şiîler üzerinde vesayet sahibi olduğu iddiasındaki İran'ın etki alanının dışına çıkması beklenmeyecek bir durumdur. Dolayısıyla bu etkinliğin uluslararası ilişkiler perspektifinden de çeşitli anlamlara sahip olduğunu vurgulamak gerekmektedir. ${ }^{79}$

Uluslararası ilişkilerde devletlerin başka devletler üzerindeki egemenlik kurma aracı olarak "güç" kullanımlarının çeşitli biçimlerde gerçekleştiğini ilk kez Bertrand Russell'ın tasniflerinde görmekteyiz. O, güç kavramının zenginlik, silahlanma, sivil otorite gibi formlarla etkili olduğunu belirtmiştir. Russell'ın ardından Joseph Nye, 1990 yılında halen tartışılan ve büyük ölçüden kabul edilen "yumuşak güç" kavramını literatüre kazandırmıştır. Nye'e göre başkaları üzerinde istediğiniz şeyleri gerçekleştirmenin, silah kullanma dışında da yöntemleri olmalıdır. Onun yumuşak güç olarak tarif ettiği, çeşitli enstrümanlarla diğerleri üzerinde istendik davranışlar geliştirmenin mümkün olduğunu savunan tezi oldukça ses getirmiştir. ${ }^{80}$ Ona göre bu güç unsurunun diğer unsurlardan en bariz fark1, sert gücün bir şeyi iterek, yumuşak gücün ise kendine doğru çekerek başarıyı hedeflemesidir. ${ }^{81}$ Nye, sinema, televizyon, uluslararası markalar, popüler kültür unsurları, İngilizce, uluslararası öğrenciler, müzik vb. araçlarla ABD’nin başka ülkeler üzerinde güç kullanımının mümkün olduğunu belirtmiş ve bunlar arasında "kültür" kavramına özel olarak değinmiştir. ${ }^{82} \mathrm{O}$, kültürün diğer ülkeler nezdinde oldukça önemli bir yumuşak güç unsuru olduğu, gelecekte siyasî arenada kültür üzerinden sürdürülecek bir mücadelenin mümkün olacağını belirtmektedir. Örneğin böyle bir mücadelede Suudi Arabistan'ın Vehhabîlik üzerinden gücünü artırmaya çalıştığını örnekleriyle ifade etmektedir. ${ }^{83}$

Bu bağlamda mezheplerin ve bunlara ait her türlü ritüelin, dinî ve mezhebî unsurların yanında yumuşak güç malzemesi olarak siyasî alanda kendine yer bulmaya oldukça müsait olduğunu belirtmek gerekir. Şî̂liğin gerek nüfus gerekse de türbeler kanalıyla en yoğun yaşandığı ülkelerden biri olan Irak, geçmişte ve günümüzde her bakımdan İran için oldukça önemli bir ülke konumundadır. Özellikle Saddam Hüseyin sonrası dönemde Şiîlerin nüfusa paralel olarak etki güçlerini artırmaları, bu bölgenin yeni dönemde İran'ın yumuşak güç unsurlarını kullanmak isteyeceği önemli bir alan haline gelmesine neden olmuştur. ${ }^{84}$ İran'ın kullandığı bu enstrümanlar arasında siyasî yardımlar, kültürel iş birlikleri ve diplomasinin yanında en önemli faktörlerden birisi mezhep birlikteliğine dayalı faaliyetlerdir. ${ }^{85}$ Nitekim bu konuda benzer fikirlere sahip olan Eşkûrî'ye göre İran'ın Erbaîn ziyaretini teşvik etmesinin en önemli nedeni, Suudîlerin Hac kanaliyla elde ettikleri prestij karşısında bir alternatif üretmek ve güç gösterisi yapmaktır. İran'ın, mezhep üzerinden öncelikle bölge Şiîlerine, sonrasında Sünnî ülkelere karşı Şîa'nın gücünü göstermeye çalıştığını, ancak böyle bir girişimin, ileride, bölgedeki mezhep çatışmasını körükleyecek bir zemin hazırlamasının söz konusu olmasından endişe duyduğunu belirtmektedir. Devamında ise bunun, İran'ın yeni tür bir siyasî aracı olduğu zikredilmektedir. ${ }^{86}$

78 - Musevî - Beyât, "Kâvişî der Âyîn-i Piyâderûy-i Erbaîn-i Hüseynî", 104; "Erbaîn Mukaddime-i Mülk-i Mehdevî Est”; Cemâlî, "Nakş-1 Erbaîn", 44.

79 - Bu konuda bir analiz için bk. Esmatullah Surosh, “İran’ın Bir Dış Politika Enstrümanı Olarak Erbâin Merasimi” (Erişim 10 Nisan 2021).

80 - Hendrik W. Ohnesorge, Soft Power: The Forces of Attraction in International Relations (Switzerland: Springer, 2020), $28-29$.

81 - Ohnesorge, Soft Power: The Forces of Attraction in International Relations, 37.

82 - Joseph S. Nye, Soft Power: The Means to Success in World Politics (New York: Public Affairs, 2004), 43-54.

83 - Nye, Soft Power: The Means to Success in World Politics, 96-97.

84 - Hasan Refî̂, "Diplomasî-yi Umûmî ve Kudret-i Nerm bâ Te’kîd ber Kudret-i Nerm-i İran der Irak”, Pejuhişnâme-i Revâbit-ı Beynelmilel 6/22 (1392/2013), 101.

85 - Refîi, “Diplomasî-yi Umûmî ve Kudret-i Nerm bâ Te’kîd ber Kudret-i Nerm-i İran der Irak”, 126.

86 - "Râhpeymâyi-i Erbaîn: Temeddünsâz yâ Âmil-i Nifâk-1 Mezhebî” (Erişim 23 Ocak 2021). 
Nitekim İranlı yazarlar tarafından da Erbaîn yürüyüşünün "yumuşak güç” unsurlarından biri olduğu sıklıkla vurgulanmaktadır. Onlara göre, her ne kadar bu yürüyüş ve ritüel, Iraklıların ev sahipliğinde gerçekleşse de burada İslam inkılabı kimliğinin bariz bir havası teneffüs edilmekte ve İran'ın her bakımdan etkisi görülmektedir. İran'ın burada olması, Suudi Arabistan gibi ülkelerin buraya dikkat kesilmesine neden olmuştur. Çünkü Irak, Arap ve Şiî bir kimliğe sahip olması dolayısıyla İslam inkılabının dünyaya açılan kapılarından birisidir. Yürüyüş, İran'ın Irak ile olan insanî faaliyetlerinin artması ve Iraklıların kültürel anlamda desteklenmesiyle iki ülke arasında iş birliğinin artmasını sağlamaktadır. ${ }^{87}$ Özellikle İran-Irak savaşından sonra İran'ın Irak üzerindeki jeopolitik üstünlüğünü kullanmaya yönelik en önemli girişimler Erbaîn'in devletin bütün gücüyle desteklenmesi yönünde olmuştur. Böylece hem Irak'taki Şiîlerin ülke için etkin bir güç olarak öne çıkması hızlanmış hem de İran'ın Şiîler üzerinden nüfuz kazanmasında önemli bir adım gerçekleşmiştir. Bu durum, İran tarafından daha önceleri dile getirilen "Şiî Hilali” anlayışının da bir sonucu olarak görülebilir. ${ }^{88}$

\section{SONUÇ}

Tarihsel süreçte İslam düşüncesinde çeşitli ekoller ortaya çıkmış, bu ekoller kendileri ile öteki olarak kabul ettikleri arasındaki farklılık noktalarını belirginleştirerek mensuplarının aidiyet bilinçlerini canlı tutmuşlardır. Sosyal bilimlerin kimlik olarak adlandırdıkları ve bizi başkalarından ayıran ya da bizi biz yapan unsurlar, doğuştan getirilebildiği gibi toplumsallaşma sonucunda da elde edilebilmektedir. Toplum tarafından yaşamımız boyunca çeşitli tecrübelerle elde ettiğimiz ve giydirilmiş kimlikler olarak tanımlanan bu aidiyetlerin en önemlileri arasında din ve mezhepler tarafından oluşturulanlar yer almaktadır.

Tarih boyunca kendilerini göreceli olarak baskı altında hisseden, azınlık konumundan kalan ve sosyal kimlikleri üzerinde tehdit algılayan grup üyeleri arasında ortak bağlılık ve dayanışma duygularının daha kuvvetli olduğu gözlenmiştir. Bu grupların ortak duygu oluşturmadaki en önemli araçlarından birisi de kutsal olarak simgeleştirilmiş kişiler ya da mekanlar üzerinden görünür hale gelmektir. Kutsal simgeler, bir toplumun yaşamının tüm boyutlarını sentezleme işlevi gören mekanizmalardır. Böylece bir dinin ya da mezhebin tüm bileşenlerini, toplumsal alanda görünür kılan özelliklerini simgeler yoluyla görmemiz mümkün hale gelmektedir.

İslam düşüncesinin iki ana ekolünden biri olan Şiîlik, diğer mezheplere nazaran toplumsal aidiyetlere göre biçimlenen ve bu aidiyetler ölçüsünde gücünü keskinleştiren bir mezhep olarak ön plan çıkmıştır. Bu aidiyet bilincinin en fazla görüldügü olaylardan biri olan Kerbelâ, geçmişte ve günümüzde Şiîliğin kendini tarih üzerinden inşa etmesinde en önemli araçlardan biri haline gelmiştir. Kerbelâ'nın tarihi süreçte acı ve keder üzerinden anlatılan bir olay olmanın ötesinde ritüel merkezli bir dindarlığı da bünyesinde barındırmasının, bu olay ve onun etrafından gelişen diğer ritüellerin Şiî inancında merkezî bir konum kazanmasına yol açmıştır. Bu ritüellerin en önemlilerinden biri de Hz. Hüseyin'in katledilmesinin kırkıncı gününe özel olarak düzenlenen Kerbelâ ziyareti ve bu ziyaret sırasında geniş katılımla gerçekleştirilen yürüyüş etkinliğidir. Erbaîn-i Hüseynî olarak da adlandırılan bu özel günün Hüseyin dışında başka bir imama nispet edilmemiş olması, bu ritüelin başlı başına bir sembol olarak görüldüğünün işaretidir.

Kırk sayısı, çok eski çağlardan bu yana başta doğu gelenekleri olmak üzere çeşitli dinler ve kültürlerde olgunlaşma, gelişme, zihinsel tamamlanma gibi anlamlar üzerinden sembolik bir değer kazanmıştır. Bu sayının bütün ilahi dinlerde de bu anlamlarına benzer şekilde kullanıldığına dair rivayetler aktarılmıştır. Şiî gelenekte de kırk sayısının sembolik bir değer olarak dile getirildiği çeşitli rivayetlere rastlanmaktadır. Ancak Hz. Hüseyin'in ölümünün kırkıncı gününe özel bir ziyaret ve etkinliğin ilk dönemlerde yeterince vurgulanmadığı, böyle bir geleneğin modern dönemlere özgü bir ritüel haline geldiği Şiî yazarlarca da kabul edilmektedir.

87 - "Râhpeymâyî-yi Erbaîn Hüviyyet-i İnk1lâb-1 İslâmî Est”.

88 - Mutkî - Erdekânî, “Tebyîn-i Câygâh ve Nakş-1 Erbaîn der İrtikâ-yı Prestij-i Jeopolitîkî-yi Teşeyyu””, 106. 
İlk olarak Şiî imamlardan Hasan el-Askerî’ye nispet edilen bir rivayet kanalıyla Erbaîn ziyaretinin müminin alametlerinden biri olarak sayılmış olması ve sonraki asırlarda özellikle dua edebiyatının önemli eserleri yoluyla bu geleneğin Şiî toplumunda yerleştiği düşünülmektedir. Ancak bu ziyareti son y1llarda önemli kılan husus, ziyaret sırasında geniş katılımla gerçekleştirilen yürüyüş etkinliğidir. Bu yürüyüş, Necef şehri ile Kerbelâ arasındaki yaklaşık 80 km'lik bir mesafede çeşitli etkinliklerle birlikte adeta bir gövde gösterisine dönüşmektedir. Yürüyüş esnasında taklit mercilerinin ofisleri tarafından kurulan çadırlarda yoğun bir şekilde vaaz, konferans, şiir, tiyatro vb. çeşitli etkinliklerle yol boyunca Şiî bilinci aktarıp diri tutacak faaliyetler icra edilmektedir. Böylece bu yürüyüş, sadece dinî anlam taşımaktan ziyade siyasî, sosyal, kültürel ve jeopolitik anlamlarıyla da oldukça çeşitli boyutlara sahip hale gelmiştir.

Bir yandan çeşitli milletlerden gelen ziyaretçiler arasında sosyalleşme yoluyla Şiî kimliğin korunmasına dair kültürel etkinlikler, diğer yandan böyle bir faaliyetin İran tarafindan uluslararası arenada yumuşak bir güç unsuru olarak kullanılmasını da beraberinde getiren büyük bir organizasyon haline gelmiştir. İran, dünyanın çeşitli coğrafyalarından gelen Şiîlerin Erbaîn ziyaretini kolaylaştırıcı tedbirler alarak onlar üzerinde bir güç kazanmakta, ve bazı yazarların da ifade ettiği üzere Suudi Arabistan'ın Hac etkinliği nedeniyle elde ettiği stratejik güce alternatif bir etkinlikle cevap verme düşüncesiyle de hareket etmektedir. Diğer yandan bölgedeki diğer ülkelere karşı da caydırıcı bir güç olarak bu faaliyetin propagandasını yapmaktadır. Bu durum haklı olarak İran'ın daha önce vurgulanan “Şiî Hilali” anlayışı noktasında kendisine oldukça önemli bir avantaj sağladığının dile getirilmesine neden olmaktadır.

Mezhebî aidiyetler ve bunlar üzerinden kazanılan kimlikler, insanların kitleler halinde belli odaklar tarafindan yönlendirilmesine imkân tanıyan güçlü bir yapıya sahiptir. Erbaîn ritüelinin Şiî toplum üzerindeki kimlik kazandırma rolünün önümüzdeki yıllarda gittikçe artacağı, bu etkinliğin gerek İran gerekse Irak tarafından siyasî alanda da sıklıkla kullanılmaya devam edeceğini belirtmek gerekmektedir. Ancak böyle bir faaliyetin gelecekte Ortadoğu'nun mezhepler tarafından belirlenmiş sinir uçlarını harekete geçirici bir fay hattı olarak önümüzde durduğunu da ifade etmeliyiz. 


\section{KAYNAKÇA}

Ahmedî, Ali. "Delâlethâ-y1 Râhbordî-yi İrtibâtât Miyânferhengî berâ-yı Hemgirâyî-yi İslâmî bâ Te’kîd ber Râhpeymâyi-yi Erbâin”. Nâme-i Ferheng ve Irtibâtât 3/1 (1397/2018), 17-38.

Arabî, Hüseyinali. "Piyâderûy-i Erbaîn-i Hüseynî: Câygâh ve Kârkerdhâ”. Marifet 28/7 (1398/2019), 45-54.

Assmann, Jann. Kültürel Bellek: Eski Yüksek Kültürlerde Yazı, Hatırlama ve Politik Kimlik. çev. Ayşe Tekin. İstanbul: Ayrıntı Yayınları, 3. Basim, 2018.

Aşkın, Muhittin. "Kimlik ve Giydirilmiş Kimlikler”. Atatürk Üniversitesi Sosyal Bilimler Enstitüsü Dergisi 10/2 (2010), $213-220$.

Bîrûnî, Ebû Reyhan el-. Maziden Kalanlar (el-Âsâr el-Bâkiye). çev. D. Ahsen Batur. İstanbul: Selenge Yayınları, 2011.

Bozan, Metin. “Tarihi Hadiselerin Konjonktürel İnşası (Şia’da Kerbela Örneği)”. Şarkiyat 9/2 (2017), 802-822. https://doi.org/10.26791/sarkiat. 341880

Ca’feriyân, Resûl. "Erbaîn-i İmam Hüseyin aleyhisselam (Yek Gozâriş-i İcmâlî)”. Makâlât-ı Târîhî. Tehran: Müesseset-i el-Hâdî, t.y.

Ca’feriyân, Resûl. “Şîa’da Dua Edebiyatı”. çev. Habip Demir. Iğdır Üniversitesi İlahiyat Fakültesi Dergisi 6 (2015), 209-237.

Cemâlî, Mustafa. "Nakş-1 Erbaîn der Muhendisi-yi Temeddün-i İslâmî”. Mutalaât-ı Mescid ve Mehdeviyet 2 (1395/2016), 27-46.

Demir, Habip. “Günümüz İran Şiiliğinde Kutsal Gün ve Geceler”. e-Makalat Mezhep Araştırmaları Dergisi 10/2 (2017), 315-351. https://doi. org/10.18403/emakalat.356099

Durûdiyân, Muhammed Cevad. "Menzer-i Ma’nevî Rûydâd-1 Piyâderûy-i Erbaîn-i Hüseynî”. Mecelle-i Menzer 10/45 (1397/2018), 56-65. https://doi.org/10.22034/manzar.2018.68625

Eliade, Mircea. Dinler Tarihi: İnançlar ve İbadetlerin Morfolojisi. çev. Mustafa Ünal. Konya: Serhat Kitabevi, 2005.

Ensârî, Mesud. "Erbaîn-i Hüseynî, Cilve-i İktidâr-1 Ümmet-i İslâmî ve Câvidânegî-yi Peyâm-1 Âşûrâ Est”. IRNA. Erişim 24 Ocak 2021. https:// اربعين-حسينى-جلوه-اقتدار-امت-اسلامى-و-جاودانگى-يِيام-عاشورا-است/Pww.irna.ir/news/84067869

Fazıl, Muhammed. “Tahlîl Mebnâ-yı Tarîhî Erbaîn-i Hüseynî”. Erişim 15 Aralık 2020. https://www.balagh.ir/content/5136

Fettâl Nîşâbûrî, Muhammed b. Ahmed. Ravzatu'l-Vâizîn ve Basîretü'l-Müteazzîn. Tehran: Neşrenî, 1366/1987.

Geertz, Clifford. Kültürlerin Yorumlanması. çev. Hakan Gür. Ankara: Dost Yayınevi, 2010.

Hâkî, Muhammed - Hüseynî, Seyyid Kâsım. "Nakş-1 Râhpeymâyî-yi Erbaîn-i Hüseynî der İcâd-1 Temeddünnevîn-i İslâmî”. Pejuhişnâme-i Meârif-i Hüseynî 5/19 (1399/2020), 93-113.

Hakyemez, Cemil. “Mezhepleri Yakınlaştırma (Takrîbü'l-Mezâhib) Çalışmalarının Değerlendirilmesi”. İslâmî Araştırmalar 29/2 (2018), 288309.

Hamaneî, Ali. "Hamâse-i Râhpeymâyi-i Erbaîn”. Erişim 23 Ocak 2021. https://farsi.khamenei.ir/newspart-index?tid=6575

Heşcîn, Zahid Gaffârî - Agâyî, Muhammed. "Piyâderûy-i Erbaîn-i Hüseyni ve Mesâbih-i Conbiş-i İctimâî”. Dâniş-i Siyâsî 14/1 (1397/2018), $1-21$.

Hüseynî Tahrani, Seyyid Muhammed Muhsin. Erbaîn der Ferheng-i Şîa. Kum: Arş-1 Endîşe, 1426/2005.

İbn A’sem Kûfî, Ebû Muhammed Ahmed b. Ali. el-Fütûh. çev. Muhammed b. Ahmed Müstevfî Herevî. thk. Gulamrızâ Tabatabâî Mecd. Tehran: İntişârât-1 İlmî ve Ferhengî, 4. Basım, 1386/2007.

İbn Kûleveyh el-Kummî, Ebu'l-Kâsım Cafer b. Muhammed. Kâmilu'z-Ziyârât. thk. Şeyh Cevad el-Kayyûmî. Kum: Sitâre, 5. Basım, $1429 / 2008$.

İbn Meşhedî, Muhammed b. Cafer. el-Mezâru’l-Kebîr. thk. Cevâd Kayyûmî İsfehânî. Kum: Defter-i İntişârât-i İslâmî, $1419 / 1988$.

İbn Şehrâşûb, Muhammed b. Ali. Menâkıbu Âl-i Ebî Tâlib Aleyhimu's-Selâm. Kum: Allâme, 1379/2000.

İbn Tâvûs, Ali b. Mûsâ. İkbâlu'l-A 'mâl. Tehran: Dâru'l-Kütübi'l-İslâmiyye, 1409/1988.

İmâmî, Seyyid Mecid - Giyâsî, Hâdî. "Hemgirâyî-i Temeddünî der Tarîk-i Ziyâret; Bâ Te’kîd ber Piyâderû-yi Ziyâret-i Erbaîn”. Do Faslnâme-i İlmî Pejûhişî Dîn ve Siyâset-i Ferhengî 9 (1396/2017), 127-148.

Kalaycı, Mehmet. "Mezhepleri veya Dinî Hareketleri Tamamlan(Ma)mış Kimliksel Süreçler Olarak Okumak”. Kur'an ve Toplumsal Bütünleşme (Mezhepler ve Dinî Gruplar Arası İlişkiler). 227-245. Bursa: y.y., 2015.

Kef'amî, İbrahim b. Ali Âmilî. el-Misbâh li'l-Kef'amî. Kum: Dâru'r-Razî, 1405/1984.

Kummî, Şeyh Abbas. Müntehiye'l-Âmâl. Tehran: İntişârât-1 Peyâm-1 Âzâdî, 4. Basım, 1390/2011.

Maalouf, Amin. Ölümcül Kimlikler. çev. Aysel Bora. İstanbul: Yapı Kredi Yayınları, 37. Basım, 2014.

Meclisî, Muhammed Bâkır. Bihâru'l-Envâr. Beyrut: Dâru İhyâ-i’t-Turâsi'l-Arabî, 1403/1982.

Musevî, Seyyid Muhammed - Beyât, Rıza. "Kâvişî der Âyîn-i Piyâderûy-i Erbaîn-i Hüseynî ve Esergozârî-yi Kârkerdhâ-yı İctimâi ve Siyâsi-yi Ân”. Ferheng ve Irtibâtât 3/1 (1397/2018), 93-116. 
Mutkî, Afşin - Erdekânî, Rıza Mollahüseynî. “Tebyîn-i Câygâh ve Nakş-1 Erbaîn der İrtikâ-y1 Prestij-i Jeopolitîkî-yi Teşeyyu’”. Nigerişhâ-yı Nov der Coğrafyâ-yı İnsânî 12/3 (1399/2020), 93-112.

Nîşâbûrî, Abdulhüseyin. Takvîm-i Şîa. Kum: İntişârât-1 Delîl-i Mâ, 13. Basım, 1391/2012.

Nye, Joseph S. Soft Power: The Means to Success in World Politics. New York: Public Affairs, 2004.

Ohnesorge, Hendrik W. Soft Power: The Forces of Attraction in International Relations. Switzerland: Springer, 2020.

Onat, Hasan. “Kerbela’y1 Doğru Okumak”. Erişim 06 Mart 2021. http://www.hasanonat.net/index.php/81-kerbela-y-dogru-okumak Pâknüyâ, Abdülkerim. "Erbaîn der Ferheng-i Ehl-i Beyt". Mübelligân, 21-33.

Pervîş, Muhsin. "Berresî-yi Zerfiyethâ-yı Temeddünsâzî der Cihân-1 İslam ve Bâ Tekye ber Piyâderûy-i Erbaîn”. Temeddün-i İslamî ve Dînpejûhî 1/2 (1398/2019), 35-55.

Refî̀, Emir Timur - Ağahasanî, Muhsin. "Nakş-1 Âmûzehâ-yı Şn̂̂ (Ta'ziye ve Ezâdârî) der Nehzet-i Meşrûtiyyet”. Pejûhişnâme-i Târîh 11/41 (1394/2015), 1-16.

Refîi, Hasan. "Diplomasî-yi Umûmî ve Kudret-i Nerm bâ Te’kîd ber Kudret-i Nerm-i İran der Irak”. Pejuhişnâme-i Revâbıt-ı Beynelmilel 6/22 (1392/2013), 99-132.

Surosh, Esmatullah, “İran’ın Bir Dış Politika Enstrümanı Olarak Erbâin Merasimi”. Erişim 10 Nisan 2021. https://iramcenter.org/iranin-bir-dis-politika-enstrumani-olarak-erbain-merasimi/?send_cookie_permissions $=\mathrm{OK}$

Sübhânîniyâ, Muhammed Takî. “Tahkîkî der bâre-i Erbaîn-i Hüseynî”. Tarih-i İslam der Âyine-i Pejûhiş 6 (1384/2005).

Şehîd-i Evvel, Muhammed b. Mekkî. el-Mezâr. Kum: Medrese-i İmam Mehdî Aleyhisselâm, 1410/1989.

Şeyh Abbas Kummî, Hacı. Mefâtîhu'l-Cinân. Kum: İntişârât-1 Âyîn-i Dâniş, 15. Basım, 1386/2007.

Şeyh Hür Âmilî, Muhammed b. Hasen. Vesâilu'ş-Şîa. Kum: Müessesetü Âli Beyt Aleyhimusselâm, 1409/1988.

Şeyh Müfid, Muhammed b. Muhammed. Kitâbu'l-Mezâr (Menâsiku'l-Mezâr). Kum: Kongre-i Cihânî-yi Hezâre-i Şeyh Müfid, $1413 / 1992$.

Şeyh Müfid, Muhammed b. Muhammed. Mesâru'ş-Şìa. thk. Mehdî Necef. Kum: Dâru'l-Müfîd, 1413/1992.

Şeyh Sadûk, Muhammed b. Ali. Emâlî. Tehran: Dâru'l-Kütübi'l-İslâmiyye, 1354/1975.

Şeyh Tûsî, Muhammed b. el-Hasen. Misbâhu'l-Müteheccid ve Silâhu'l-Mute'abbid. Beyrut: Müessesetu Fıkhi'ş-Şîa, 1411/1990.

Şeyh Tûsî, Muhammed b. el-Hasen. Tehzîbu'l-Ahkâm. thk. Hasan el-Mûsevî Horasan. Tehran: Dâru'l-Kütübi'l-İslâmiyye, $1407 / 1986$.

Tabatabaî, Muhammed Ali Kâdi. Tahkîk der bâre-i Evvel-i Erbâin-i Hazret-i Seyyidu'ş-Şuhedâ (a.s.). Tehran: Vezâret-i Ferheng ve İrşâd-i İslâmî, 3. Basım, 1390/2011.

Ümit, Mehmet. “Zeydiyye Mezhebi’nde Hz. Hasan, Hz. Hüseyin ve Kerbelâ”. İlahiyat Akademi 5 (2017), 129-146.

“Âyâ Pes ez İctimâ' ‘14 Milyonî Erbaîn’ Âmâr-1 Fovtîhâ-i Korona der Kerbelâ ve Necef Sifr Şodeend?” Erişim 12 Aralık 2020. https://factnameh.com/fact-checks/2020-10-30-covid19-arbaee-karbala.html

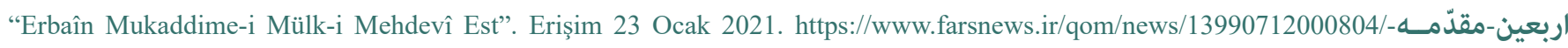
مُلك-مهدوى-است

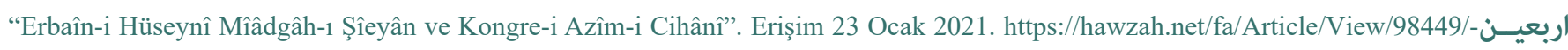

$$
\text { عظيم-جهانى-2\%2\%80\%8C }
$$

“İmam Hâmaneî: Be Şiîyân yâd Dâdend İncâ Mahall-i İctimâ-i Şomâst”. Erişim 02 Ocak 2021. http://panahian.ir/post/35

“Müşâreket-i 14 Milyon Zâir der Merâsim-i Erbaîn-i Hüseynî”. Erişim 12 Aralık 2020. https://alkafeel.net/news/index?id=11717\&lang=pr

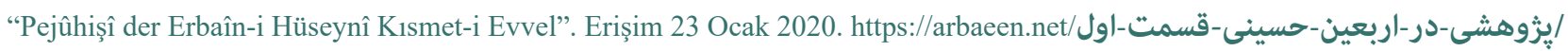

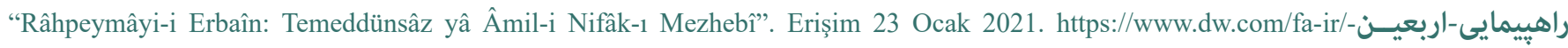
a-41321946/تمدنسـاز-يا-عامل-نفاق-مذهبى

“Râhpeymâyî-yi Erbaîn Hüviyyet-i İnk1lâb-1 İslâmî Est”. Erişim 23 Ocak 2021. http://www.iscanews.ir/news/1031614/هييمايى-اربعيـن هويت-انقلاب-اسلامى-است

“Temeddün-i İslâmî Nâşî ez Ferheng-i Âşûrâ ve Erbaîn Mâye-i Tahakkuk-i Ân Est”. Erişim 23 Ocak 2021. https://www.tasnimnews.com/fa/

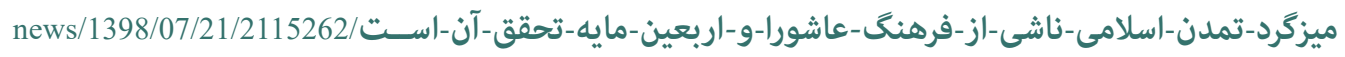




\section{EXTENDED ABSTRACT}

One of the most important factors in making the identities we carry as individuals become clear is our different affiliations shaped by the social and cultural environment. These belongings are defined as "clothed identities" by social scientists. One of the most important belonging elements that individuals have is those obtained through certain groups. One of the most important conditions of belonging to a group as an individual arises as a result of the association with the common past of that group and its reflection on daily practices. In Assmann's words, this is called "common memory" or "cultural memory". This memory passes from generation to generation by being passed on through thought carriers. One of the most important factors that carry ideas to future generations is the elements of belonging produced by religions and sects.

One of the most common functions of religions and sects is to mediate the continuation of the past by remembering, enacting and repeating social phenomena that will appeal to the imagination of their members. Rituals, one of the most important tools of this, have functions beyond being repeated phenomena in a certain part of time. One of its most important functions is to preserve group identity and belonging in the process of transferring culture to new generations through repetition.

It is possible to find one of the most important examples of sectarian belongings based on social interaction through sacred symbols and rituals in the historical process in the shaping of the Shiite society. Shiism, with the effect of being a minority, has been a sect that has been shaped according to social belongings compared to other sects and sharpened its power according to these belongings. In the Shiite thought, Karbala is not seen as an incident that took place and ended in a certain period of history. After completing the formation process of the sect, the event of Karbala lost its characteristic of being a historical event as a result of the reconstruction of the past with new and original contents in every period, and was kept alive by being transformed into "selected and transferred trauma".

According to the Hijri calendar, which is seen as one of the most important days of the Shiite tradition, 20 Safar days are called "Arba'eene Husaini". The visit on this day is regarded as one of the symbols of the Shia culture. One of the most important factors that make Arba'een stand out compared to other ceremonies and make him have such a different meaning is the march activity between Najaf and Karbala cities with a wide participation. This march has come to the fore as an event with various dimensions, including political, social, cultural and geopolitical meanings, rather than just having a religious meaning. It is seen that until recently, the special march for Arba'een was an activity carried 
out only by Iraqi Shiites with local followers, and it has reached an international dimension recently. With the disappearance of the Ba'ath power in 2003, the social and political visibility of the Shiites increased considerably, and a new era entered, the Arba'een march continued to be carried out more gloriously every year and expanded with new facts and interpretations.

The effort to see the Arba'een march as a social movement, not a state-based organization, is an issue emphasized by the Shiites. In Shiite circles, it is frequently emphasized that Arba'een cannot be limited only as the visit of Husain but is also an activity that will enable an Islamic model against the secular Western civilization.

One of the most important functions Arba'een has undertaken in recent years, in addition to assuming various social and cultural meanings, is the gradual gaining of a political dimension. The political dimension of this march can be read as the projection of the Arab Spring, which started in the region after 2011, in the Shiite world. It is observed that Arba'een started to be symbolized by gaining a meaning intertwined with the concept of "Islamic Awakening". On the one hand, cultural activities on the preservation of Shi'ite identity through socialization among visitors from various nations, and on the other hand, it has become a large organization that brings with it the use of such an activity by Iran as an element of soft power in the international arena. Iran gains power over the Shiites coming from various geographies of the world by taking measures to facilitate their visit to Arba'een, and as some authors have stated, it acts with the idea of responding to the strategic power that Saudi Arabia has gained due to the Hajj activity with an alternative activity. On the other hand, it propagates this activity as a deterrent force against other countries in the region. This situation rightly causes it to be stated that Iran has given itself a very important advantage in the "Shiite Crescent" understanding emphasized earlier. 